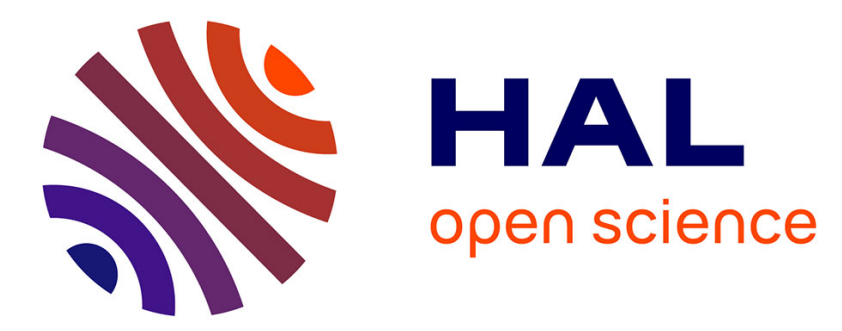

\title{
Acute respiratory distress syndrome after chest trauma: epidemiology, specific physiopathology and ventilation strategies
}

Séverin Ramin, Jonathan Charbit, Samir Jaber, Xavier Capdevila

\section{To cite this version:}

Séverin Ramin, Jonathan Charbit, Samir Jaber, Xavier Capdevila. Acute respiratory distress syndrome after chest trauma: epidemiology, specific physiopathology and ventilation strategies. Anaesthesia Critical Care \& Pain Medicine, 2018, 38 (3), pp.265-276. 10.1016/j.accpm.2018.09.009 . hal01903859

\section{HAL Id: hal-01903859 \\ https://hal.science/hal-01903859}

Submitted on 18 Jun 2020

HAL is a multi-disciplinary open access archive for the deposit and dissemination of scientific research documents, whether they are published or not. The documents may come from teaching and research institutions in France or abroad, or from public or private research centers.
L'archive ouverte pluridisciplinaire $\mathbf{H A L}$, est destinée au dépôt et à la diffusion de documents scientifiques de niveau recherche, publiés ou non, émanant des établissements d'enseignement et de recherche français ou étrangers, des laboratoires publics ou privés. 


\title{
Acute respiratory distress syndrome after chest trauma: Epidemiology, specific physiopathology and ventilation strategies
}

\author{
Severin Ramin ${ }^{a}$, Jonathan Charbit ${ }^{a, *}$, Samir Jaber ${ }^{b}$, Xavier Capdevila ${ }^{a}$ \\ ${ }^{a}$ Trauma Intensive and Critical Care Unit, Lapeyronie University Hospital, 34090 Montpellier, France \\ ${ }^{\mathrm{b}}$ Intensive Care Unit and Transplantation, Critical Care and Anaesthesia Department (DAR B), Saint-Éloi University Hospital, 34090 Montpellier, France
}

\section{Contents}

1. Background

2. Study design and literature search . . . . .

3. Epidemiology of ARDS in chest trauma ...

4. Physiopathology of ARDS in chest traum

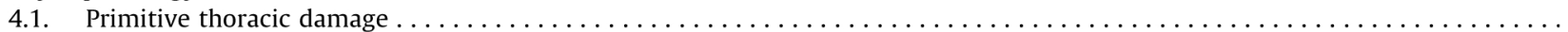

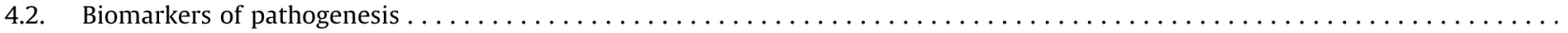

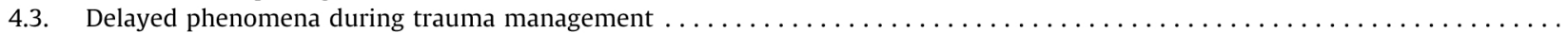

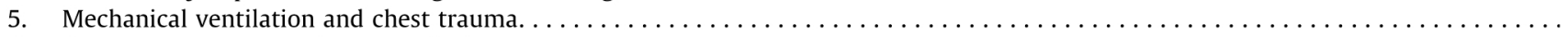

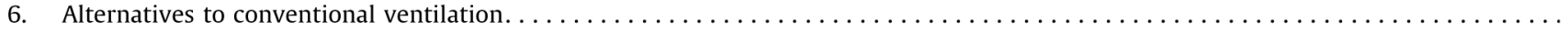

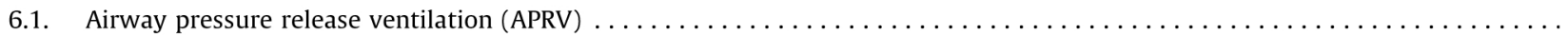

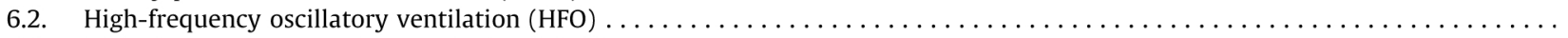

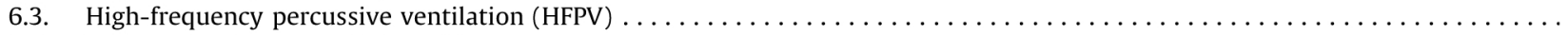

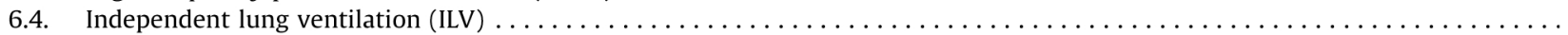

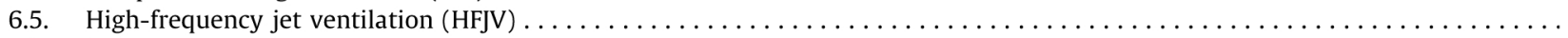

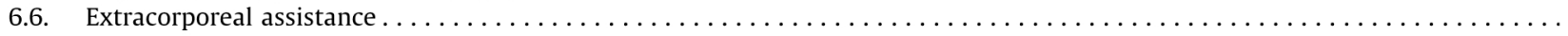

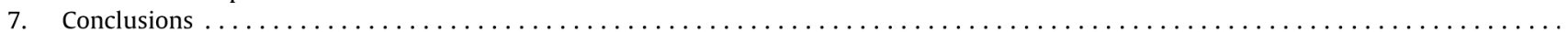

References

\section{Background}

Traumatic chest injuries are responsible for significant morbidity and the cause of trauma-related death in $20 \%-25 \%$ of cases [1]. Traffic accidents and falls are thus the most causes of these injuries [1]. Thoracic trauma can include multiple injuries, mainly osseous (ribs, sternal fractures, flail chest), pulmonary contusions or lacerations, pneumothoraxes and pleural effusions, and sometimes involve wounds to the heart and vessels (aortic dissection, cardiac contusion) or diaphragm [2]. Chest trauma is also often associated with severe injuries to other regions, particularly to the head, abdomen or extremities [3]. Following trauma, patients with thoracic injuries are at risk of developing acute lung injury (ALI) and acute respiratory distress syndrome (ARDS). This worsening of respiratory function can lead to requirement for mechanical ventilation [4]. ARDS may thus occur because of direct injury to the lung or due to secondary

\footnotetext{
* Corresponding author. Deépartement d'Anestheésie Reéanimation Lapeyronie, Hôpital Lapeyronie, 371, avenue du Doyen-G.-Giraud, 34090 Montpellier, France. E-mail addresses: severin.ramin@gmail.com (S. Ramin), j-charbit@chu-montpellier.fr (J. Charbit), s-jaber@chu-montpellier.fr (S. Jaber), X-capdevila@chu-montpellier.fr (X. Capdevila).
}

mechanisms induced by the trauma setting. In addition, changes to gas exchange may also be generated or aggravated by mechanical ventilation as a result of volotrauma barotrauma, biotrauma, or ventilation-associated pneumonia [5]. Many mechanical ventilation strategies have been tried in trauma patients in the last 30 years to determine the optimal method of maximizing gas exchange with minimal lung damage [6]. The aim of the present work has been to establish the current state of ARDS in relation to chest trauma and to review the different mechanical ventilation strategies used in this setting. Non-invasive ventilatory support and ventilatory weaning are two complex study fields with an available literature very limited. These topics could be the subject of another systematic review and will not discussed in the present work.

\section{Study design and literature search}

By selecting several major key topics, our aim was to investigate the indications for several alternative management of conventional mechanical ventilation in severe or multiple traumas, as well as their foremost effects.

We only included data from studies that enrolled adults (aged $>18$ years) affected by ARDS induced by blunt or 


\begin{abstract}
Abbreviations
APRV airway pressure release ventilation

ARDS acute respiratory distress syndrome

ECMO extracorporeal membrane oxygenation

HFO high-frequency oscillation ventilation

HFJV high-frequency jet ventilation

HFPV high-frequency percussive ventilation

ILV independent lung ventilation

MOF multi-organ failure

PEEP positive end-expiratory pressure

TRALI transfusion-related acute lung injury
\end{abstract}

penetrating trauma, into an emergency department, a trauma service or an intensive care unit (ICU). Randomised and nonrandomised controlled trials, as well as observational studies including cohort, case-control and case series, were analysed. The list of studies was updated by a number of clinical databases, including PUBMED, MEDLINE and EMBASE, from January 1990 until today. The selected keywords were mechanical ventilation and trauma, which were cross-referenced with flail chest, pulmonary contusion, chest injury, blunt chest trauma, acute lung injury (ALI), acute respiratory distress syndrome (ARDS), respiratory failure, airway pressure ventilation (APRV), high frequency oscillation (HFO), high frequency percussive ventilation (HFPV), independent lung ventilation (ILV), high frequency jet ventilation (HFJV), extracorporeal membrane oxygenation (ECMO), extracorporeal life support (ECLS) and multi organ failure (MOF). Because this was a retrospective review, ethical approval was deemed not necessary for data collection.

\section{Epidemiology of ARDS in chest trauma}

Blunt chest trauma is involved in nearly one-third of acute trauma admissions to the hospital. Traditionally, respiratory failure and ARDS are frequent following chest trauma, but are poorly documented in the literature. Chest trauma is often caused by high-velocity blunt trauma, which explains the adverse consequences. Patients with thoracic injuries are at high risk for ARDS [7], occurring in 10\%-25\% of cases depending from trauma severity $[8,9]$. ARDS in trauma patients account for about $5 \%$ of all ARDS [10]. The delay in the onset of ARDS is variable according to its cause; ARDS may indeed occur several days after a trauma. Mortality attributable to trauma-related ARDS varies from $20 \%$ to $80 \%$ with the severity of injuries [11]. Moreover, ARDS in trauma patients has been associated with longer hospital stay, increased costs, and worse long-term health-related quality of life [12]. In cases of chest trauma, initiation of mechanical ventilation during the initial management is also very variable (ranging from $23 \%$ to $75 \%$ ) because it depends on the severity of the trauma, the degree of underlying lung disease, associated injuries, and early surgical requirements [13]. Similar to the medical setting, mechanical ventilation in cases of trauma is well known to be associated with a high risk of nosocomial pneumonia (between 30\% and 50\%), leading also to respiratory failure and ARDS [14].

Many risk factors for early and delayed respiratory failure have been described for chest trauma, including thoracic injuries, but also several extra-thoracic injuries. Deformation of the thoracic osseous cage caused by rib and sternum fractures or flail chest has been strongly associated with ARDS, as well as the presence and the amount of pulmonary contusions, pneumothoraces and hemothoraces [15]. A pulmonary contusion surface of $20 \%$ of the overall pulmonary parenchyma was documented as a robust predictive threshold for ARDS (positive predictive value 80\%) [16]. Lung ultrasonography may help diagnose pulmonary contusions as soon as admission and follow their evolution, in order to identify trauma patients at risk of developing ARDS [17]. In addition, many extra-thoracic injuries (compartment abdominal syndrome, major long bone fractures and unstable pelvic fractures, and head trauma) were also identified as independent risk factors of ARDS [18]. Among other risk factors of ARDS, age older than 55 years, male gender, active smoker, important comorbidities such as diabetes have been clearly determined, as well as initial massive fluid therapy, volume and type of blood products administered, number of surgical procedures [19].

\section{Physiopathology of ARDS in chest trauma}

Multiple causes have been associated with the development of ARDS in cases of chest trauma. Hypoxemic thoracic injuries lead to local and systemic aggravating mechanisms that induce ARDS in the hours after trauma, with an interval of several hours or days. Fig. 1 summarises the different phenomena that lead to ARDS.

\subsection{Primitive thoracic damage}

Many thoracic injuries can lead to ALI and alteration of gas exchange. All these injuries can induce a decrease in functional residual capacity and alveolar recruitment, leading to ventilationperfusion mismatch and intrapulmonary shunt [20].

Pulmonary contusion is a nosologic entity often found in patients with chest trauma (70\%-80\%). Alveolar derecruitment may result from direct alveolo-capillary membrane changes. In addition with alveolar blood filling, an increasing alveolo-capillary membrane permeability indeed occurs, leading to alveolar oedema, surfactant destruction and hypoxemia [21].

Alveolar collapse may also be a consequence of impairment in thoracic expansion and change in the mechanics of spontaneous breathing. Shallow tidal breathing and a lack of deep inspirations promote atelectasis, V/Q mismatch, and hypoxemia, leading to pneumonia and respiratory failure. Sternal and ribs fractures, flail chest and thoracic spine fractures are the main injuries involved in this pathogenic phenomenon. Impairment of ventilatory mechanics is thus strongly affected by pain [22]. Rib fractures are reputed to be very painful and to limit deep breathing. Optimal analgesia in these patients was found to be associated with reduced need for mechanical ventilation and lower incidence of ARDS [22]. In this setting, regional anaesthesia, such as thoracic epidural analgesia, paravertebral nerve block may clearly improve survival of trauma patients [23]. In addition, osseous injuries, diaphragmatic wounds or ruptures may also lead to distortion of diaphragmatic movement and ventilatory problems [24]. Reduction of shallow tidal breathing and inspiratory amplitude therefore promotes atelectasis, ventilation-perfusion ratio mismatch and ARDS.

Alveolar derecruitment may be generated by extrinsic lung compression; pleural effusions (pneumothoraces and hemothoraces) and intraperitoneal organs in cases of diaphragmatic hernia are the main causes [25]. Furthermore, tracheal or bronchial injuries may also increase the compressive mechanisms in cases of massive air leaks [1].

\subsection{Biomarkers of pathogenesis}

ARDS is a progressive inflammatory disease of the lungs. The acute phase is characterised by an important and uncontrolled 


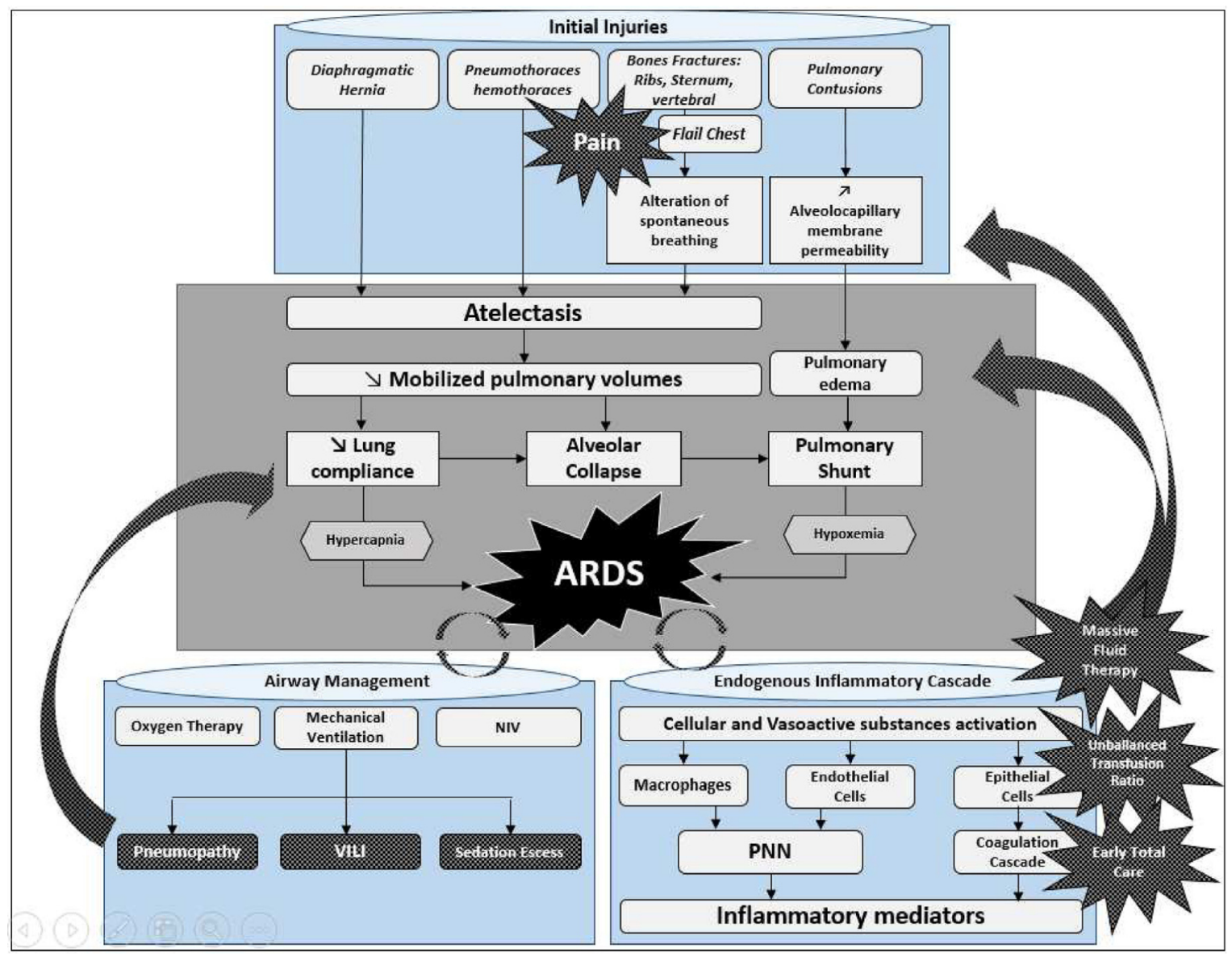

Fig. 1. Physiopathogenesis of acute respiratory distress syndrome (ARDS) related to trauma. This figure explains the different physiopathological mechanisms leading to ARDS in cases of chest trauma, including initial and delayed ARDS. Secondary aggression mechanisms are also represented.

inflammatory response in the lung tissues. It results a significant accumulation of neutrophils and macrophages [26]. The intense and prolonged activation of the immune system in response to initial injury leads to immunological reaction. The importance of this inflammatory response depends obviously on the degree of the trauma, but also on the genetic profile of patients. A previous work by Tompkins et al. [27] showed in severe trauma population that the early leukocyte genomic response was associated with simultaneously increased expression of genes involved in the systemic inflammatory, innate immune, and compensatory anti-inflammatory responses, as well as in the suppression of genes involved in adaptive immunity. All these modifications induce a massive release of damage-associated molecular pattern molecules from injured tissues. These specific biomarkers are different according to the kind of damaged cells [28]. Endothelial injuries generate a blood accumulate in the pulmonary alveoli associated with a raise of vascular permeability and inflammatory cells. Among the main endothelial biomarkers, Ang-2, ICAM-1, selectins and VEGF can be cited [29]. Epithelial injuries involve biomarkers leading to dysfunction of type I, type II alveolar cells and clara cells. Massive release of epithelial biomarkers such as sRAGE are responsible for dysfunction of capillary-alveolar barrier [30]. Biomarkers such as surfactant protein B also play critical roles in ARDS developing by the reducing of alveoli surface tension and repair phenomena of injured lung tissues [31]. Finally, the increasing of several clara cells, such as clara cell protein 16 , decreases protection of lung tissues against inflammation, oxidative stress and fibrosis in ARDS [32].

\subsection{Delayed phenomena during trauma management}

Several harmful factors can subsequently lead to the occurrence or aggravation of ARDS in the days after the initial chest trauma. Pulmonary oedema results from extravascular diffusion because of increased capillary permeability, and decrease in oncotic pressure [33]. Limitation of capillary pressure by fluid restriction has been shown in favour of a decreasing of lung oedema [34]. Similarly, the volume and the type of blood products administrated (i.e. fresh frozen plasma) have long been blamed for lung damage, so-called transfusion-related acute lung injury (TRALI). However, a recent prospective trial has proved that aggressive administration of fresh frozen plasma and platelets in patients with massive bleeding patients was not associated with a higher rate of respiratory failure [35]. Large volumes of fluid therapy administrated concomitantly with massive transfusion are probably the origin in previous reports of ARDS development. Restrictive fluid strategy applied in coagulopathic patients was indeed associated recently with a lower incidence of TRALI. Another significant risk factor of ARDS is the early total care strategy that may potentiate the systemic inflammation cascade and its adverse consequences [36]. Intramedullary nailing may thus cause an increase in intramedullary pressure leading to release of bone marrow and fat into the venous blood system, which dramatically increased the incidence of ARDS and MOF [37]. Early intramedullary femoral nailing increases for example the incidence of ARDS more than four times in cases of severe chest trauma (33\% versus 8\%) [38]. Finally, Ventilator-associated pneumonia is a frequent complication may lead to ARDS. This may increase the risk of multiple organ failure and death [14]. 


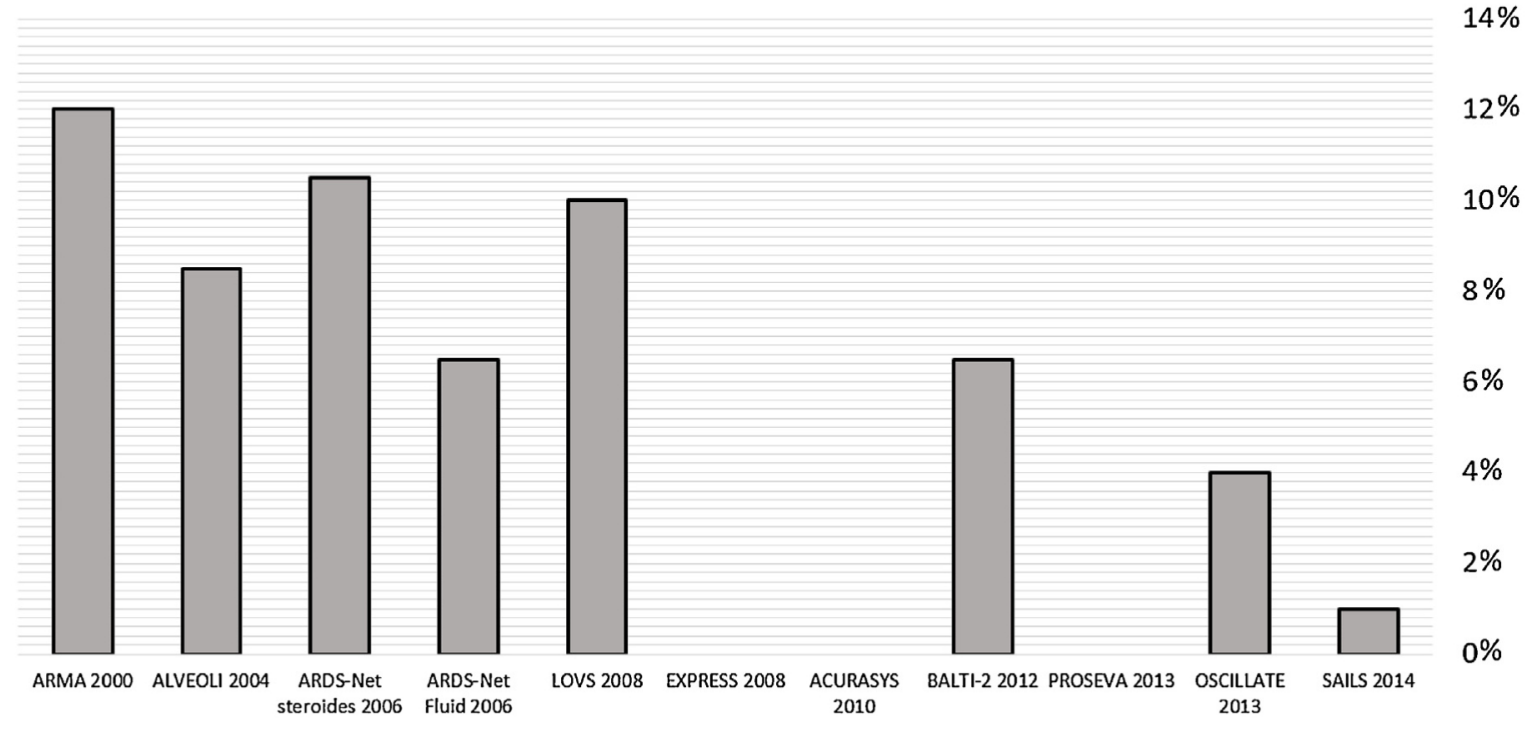

Fig. 2. Multicenter double-blind trials of acute respiratory distress syndrome (ARDS): percentage of trauma patients included.

\section{Mechanical ventilation and chest trauma}

Chest trauma is associated with the need for mechanical ventilatory support, especially in the presence of pulmonary contusions, multiple rib fractures or flail chest [39]. However, mechanical ventilation may cause itself or potentiate ventilatorinduced lung injury [40]. Indeed, in patients with ARDS, excessive pressure or volume applied to the lung may cause regional parenchymal over distention, also called barotrauma and volotrauma. Cyclic opening and closing may also create shear stresses at the interface between open and closed lung regions (atelectrauma) [40]. Finally, local activation of the inflammatory cascade leads to destruction of the extracellular matrix and biotrauma. Consequently, ventilator strategies aimed at reducing parenchymal damage and the inflammatory response. Recent studies have shown significant benefits of lung-protective ventilation strategies [41]. As a consequence, most experts strongly recommend the use of a physiological low tidal volume of $6-8 \mathrm{~mL} / \mathrm{kg}$ (predicted body weight) and limiting the inspiratory plateau pressure under $30 \mathrm{cmH}_{2} \mathrm{O}$ in trauma patients [42]. Positive end-expiratory pressure (PEEP) seems to be moreover indispensable to optimize oxygenation. The level of PEEP must thus be titrated in order to define the optimal PEEP [43]. The use of rescue therapies such as neuromuscular blockade improves outcomes in ARDS patients, limitation of work of breathing, reduction of resistance from the chest wall and abdomen, and improvement in ventilator synchrony [44]. In patients with severe ARDS, early application of prolonged prone-positioning sessions significantly decreased mortality and improve oxygenation in various degrees of lung injury $[45,46]$. However, these strategies have never been specifically studied in case of chest trauma with associated ARDS, especially in case of multiple ribs fractures or flail chest [47]. Indeed, no study is available on the target trauma population concerning benefit of protective ventilation, the use of neuromuscular blockade, the goal of sedation, or the use of prone position. Therefore, management in trauma patients is based on an extrapolation of the medical setting since they were established on patients with ARDS from multiple origins, post-traumatic ARDS representing indeed only $8 \%$ to $13 \%$ of cohorts (Fig. 2).

Conversely, the open lung concept has been studied more with regard to trauma. The aim of open lung is to maintain open alveoli during inspiration and expiration using of significant PEEP, and to recruit atelectasis alveoli by increasing inspiratory pressure for a short period. High-frequency inverse-ratio ventilation was described in chest trauma as an alternative to external PEEP, which allows to generate alveolar and intrinsic PEEP trapping [48]. Recruitment manoeuvres reported in several studies used predefined opening pressures (i.e. $50,65,80 \mathrm{cmH}_{2} \mathrm{O}$ ) with a targeted goal of arterial pressure oxygenation, considered as a robust indicator of optimal alveolar recruitment [48]. Many results indicate that application of the open lung concept is a reasonable strategy for ventilation in cases of severe chest trauma [49]. However, the use of high PEEP levels may be associated with important stress and strain in lung parenchyma, severe hypotension and a substantial reduction of cardiac output [50]. Furthermore, injured lung parenchyma is well-known to be heterogeneous in the trauma setting, leading to overdistention of healthy alveoli in case of too high PEEP. High PEEPs and recruitment manoeuvres may generate a massive air leak in cases of tracheobronchial rupture or bronchopleural fistula, strengthening the necessity to determine the optimal ventilation according to lesional status.

\section{Alternatives to conventional ventilation}

Conventional mechanical ventilation may be not efficient in some cases of ARDS related to chest trauma. Alternative methods of ventilation can then be used. These ventilatory strategies were thus studied in this specific setting. The results of several trials are summarized in Table 1.

\subsection{Airway pressure release ventilation (APRV)}

APRV is a ventilator strategy that may be used in critically ill patients affected by ARDS [51,52]. APRV involves bi-level positive airway pressure with a double-valve flow system; it is a pressurelimited, time-cycled method of ventilation that permits spontaneous breathing at any time throughout the respiratory cycle. This method allows alveolar recruitment beyond the inspiration phase [53]. The main difference from the traditional pressure mode is that the lower pressure level is short (e.g. 1-3 s), whereas the upper pressure level is particularly prolonged (e.g. $7-12$ s). The tidal volume does not therefore depend only on differences between the two pressure levels, but is mainly generated by spontaneous breathing activity.

A prospective randomised trial comparing APRV and ARDS network protocols in trauma patients proved that APRV was safe 
and provided the same quality of oxygenation $\left(\mathrm{PaO}_{2} / \mathrm{FiO}_{2}\right.$ ratio $)$ as the conventional method [54]. On the other hand, Maung et al. [55] found that duration of ventilation was increased with APRV compared the conventional methods in trauma patients with respiratory failure. Similarly, a systematic review comparing early APRV initiation versus a conventional ventilator strategy in trauma patients at high risk of ARDS showed a reduction of mortality using early APRV [56]. Despite increasing evidences on improved oxygenation and haemodynamics, patient comfort, and safety, many issues regarding this unconventional method remain unanswered. Reduction in mortality with APRV in cases of ARDS is indeed still under debate, which requires cautious for a large use of this mode in chest trauma.

\subsection{High-frequency oscillatory ventilation (HFO)}

HFO is a rescue method for patients with severe respiratory distress, which uses the concept of gas exchange diffusion and

Table 1

Important characteristics of major clinical studies of alternative ventilatory strategies in ARDS related to trauma (2001-2015).

\begin{tabular}{lllll}
\hline Study & Year & Design & $\begin{array}{l}\text { No. in Initial } \\
\text { cohort } \mathrm{PaO}_{2} / \mathrm{FiO}_{2}\end{array}$ & $\begin{array}{l}\text { Overall Study protocol } \\
\text { survival } \\
(\%)\end{array}$
\end{tabular}

Airway pressure release ventilation (APRV) Maxwell et al. [45] 2010 randomized controlled

$63 \quad 350 \pm 150 \quad 93$

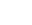

High-frequency oscillation (HFO)

Funk et al. [51] 2008
Retrospective

observational

0

$96 \pm$

87

Prospective

observational

13

$86 \pm 12 \quad 53$
Vrettou et al. [52]

2013

High-frequency percussive ventilation (HFPV) Salim et al. [55]
Retrospective observational
APRV ( $n=31$ ) vs conventional mechanical ventilation (CMV)

$(n=32)$

Ventilatory setting:

CMV group:

Tidal volume before:

$6.4 \pm 1.2 \mathrm{~mL} / \mathrm{kg}$

PEEP: $10 \mathrm{cmH}_{2} \mathrm{O}$

Plateau pressure: $<30 \mathrm{cmH}_{2} \mathrm{O}$

APRV group:

Inspiratory time: $4-5 \mathrm{~s}$

Expiratory time: $0.4-1 \mathrm{~s}$

Respiratory rate: $10-30 / \mathrm{min}$

Time to APRV: immediately after

initiation of mechanical

ventilatory support

Duration of APRV: during

control-assisted ventilatory

support

APRV $(n=75)$ vs. conventional Patients presented minor or mechanical ventilation $(n=234)$

Time to APRV: $24 \mathrm{~h}$

Duration of APRV: not

communicated

Ventilatory setting: not

communicated

Time to HFO: not

communicated

Duration of HFOV: $5 \pm 1.5$ days

Conventional ventilatory

setting:

Tidal volume before HFO

initiation: $8.3 \pm 1.3 \mathrm{~mL} / \mathrm{kg}$

Minute ventilation before HFO

initiation: $15.0 \pm 2.9 \mathrm{~L} / \mathrm{min}$

PEEP before HFO initiation:

$14.6 \pm 2.6 \mathrm{cmH}_{2} \mathrm{O}$

Plateau pressure:

$30.4 \pm 4.5 \mathrm{cmH}_{2} \mathrm{O}$

Time to HFO: $35 \mathrm{~h}$

Duration of HFO: not

communicated

Conventional ventilatory

setting was not communicated

Time to HFPV: immediately in cases of refractory hypoxaemia under conventional mechanical ventilation

Duration of ILV: until $\mathrm{PaO}_{2}$ recovery according to study physicians
Few patients presented ARDS in each group (35\%-45\%)

No significant difference was found between the 2 groups

Patients presented minor or
moderate ARDS in the APRV group

Many patients in the conventional mechanical group did not present ARDS (mean $\mathrm{PaO}_{2} / \mathrm{FiO}_{2}: 243 \pm 120$ ) Ventilator days were greater in the APRV group (19 vs. 10 days)

Most patients had pulmonary contusions

A significant improvement in oxygenation index was found after HFO initiation A significant improvement in $\mathrm{PaO}_{2} / \mathrm{FiO}_{2}$ was found after HFO initiation

Most patients presented ARDS and a traumatic brain injury A significant improvement in $\mathrm{PaO}_{2} / \mathrm{FiO}_{2}$ was found after initiation of HFO
Most patients presented ARDS and a traumatic brain injury A significant improvement in $\mathrm{PaO}_{2} / \mathrm{FiO}_{2}$ was found 
Table 1 (Continued)

$\begin{array}{llllll}\text { Study } & \text { Year } & \text { Design } & \begin{array}{l}\text { No. in } \\ \text { cohort }\end{array} \mathrm{PaO}_{2} / \mathrm{FiO}_{2} & \begin{array}{l}\text { Overall Survival } \\ \text { study protocol }\end{array}\end{array}$

Eastman et al. [54] $2006 \quad$ Retrospective

observational

Independent lung ventilation (ILV)

Katsaragakis et al. [58] 2005

Sawulski et al. [59]

2012

Case report

123

100

Retrospective observational

igh-frequency jet ventilation (HFJ

Riou et al. [62] 2001

Extracorporeal membrane oxygenation (ECMO)

Cordell-Smith et al [73]. 2006

Retrospective

observational

Arlt et al. [75]

2010

Prospective

observational

Bonacchi et al. [67]

$12 \quad 90 \pm 50 \quad 58$

2

48

87

Prospective setting was not communicated Synchronous and asynchronous ventilation were used Time to ILV: $25 \mathrm{~h}$ Duration of ILV: 5 days Synchronous then asynchronous ventilation settings were used Time to ILV: $48 \mathrm{~h}$ Duration of ILV: 2 days

Conventional ventilatory setting:

Tidal volume: $659 \pm 151 \mathrm{~mL}$ PEEP: $10 \pm 3 \mathrm{cmH}_{2} \mathrm{O}$

Time to HFJV: $7 \pm 6 \mathrm{~h}$ Duration of HFJV: \pm 7 days

Heparinization: systemic heparin was adapted to activated clotting time Time to extracorporeal life support (ECLS): $69 \mathrm{~h}$ Duration of ECLS: $141 \mathrm{~h}$ VV-ECMO: 7 patients VA-ECMO: 3 patients Heparinization: no heparin was used after initiation of ECMO

Time to ECLS was not communicated

Duration of ECLS: 5 days observational

VV-ECMO: 4 patients

VA-ECMO: 10 patients

Heparinization free time on ECLS: $20.7 \pm 19.8 \mathrm{~h}$

Systemic heparin was adapted to activated clotting time Time to ECLS: $351.8 \pm 242 \mathrm{~min}$ Duration of ECLS $128.7 \pm 113 \mathrm{~h}$
VV-ECMO: 26 patients

pECLA: 26 patients Heparinization: systemic heparin was adapted to reach a partial thromboplastin time of 40-50 s

Time to ECLS: $5 \pm 8 \mathrm{~h}$

Duration of ECLS: $7 \pm 4$ days
A significant improvement in the oxygenation index was found after initiation of HFPV A significant improvement in $\mathrm{PaO}_{2} / \mathrm{FiO}_{2}$ was found after initiation of HFPV

Patients presented unilateral or asymmetrical lung trauma A significant improvement in $\mathrm{PaO}_{2} / \mathrm{FiO}_{2}$ was found after initiation of ILV

Patient presented a unilateral chest lesion Improvement in ventilatory settings was found after initiation of ILV

Patients with severe pulmonary contusions

A significant improvement in $\mathrm{PaO}_{2} / \mathrm{FiO}_{2}$ was found after initiation of HFPV

A significant improvement in acid base correction was found after initiation of HFPV

Mean time to ECMO was $61 \mathrm{~h}$ for survivors versus $87 \mathrm{~h}$ for non-survivors

Patients presented active bleeding

A significant improvement in $\mathrm{PaO}_{2} / \mathrm{FiO}$ was found after initiation of ECMO

A significant improvement in cardiac index, mean arterial pressure, blood lactate, $\mathrm{PaO}_{2}$, $\mathrm{PaCO}_{2}$, and acid base correction within $3.5 \pm 1.5 \mathrm{~h}$ of initiation of ECMO was found

pECLA is an extracorporeal carbon dioxide removal system A significant improvement in cardiac index, mean arterial pressure, blood lactate, $\mathrm{PaO}_{2}$, $\mathrm{PaCO}_{2}$, and acid base correction after initiation of ECMO was found 
Table 1 (Continued)

\begin{tabular}{|c|c|c|c|c|c|c|c|}
\hline Study & Year & Design & $\begin{array}{l}\text { No. in } \\
\text { cohort }\end{array}$ & $\begin{array}{l}\text { Initial } \\
\mathrm{PaO}_{2} / \mathrm{FiO}_{2}\end{array}$ & $\begin{array}{l}\text { Overall } \\
\text { survival } \\
(\%)\end{array}$ & Study protocol & Comment \\
\hline Wu et al. [72] & 2014 & $\begin{array}{l}\text { Prospective } \\
\text { observational }\end{array}$ & 20 & 56 & 70 & $\begin{array}{l}\text { VV-ECMO: } 20 \text { patients } \\
\text { Heparinization: systemic } \\
\text { heparin was adapted to } \\
\text { activated clotting time } \\
\text { Systemic heparin strategy was } \\
\text { utilized in } 55 \% \text { of patients } \\
\text { Time to ECLS: } 69 \mathrm{~h} \\
\text { Duration of ECLS: } 10 \pm 5 \text { days }\end{array}$ & $\begin{array}{l}7 \text { cases of massive } \\
\text { haemorrhage during ECMO, } \\
3 \text { were lethal } \\
\text { A significant improvement in } \\
\mathrm{PaO}_{2} / \mathrm{FiO}_{2} \text { was found after } \\
\text { initiation of ECMO }\end{array}$ \\
\hline Guirand et al. [69] & 2014 & $\begin{array}{l}\text { Retrospective } \\
\text { controlled }\end{array}$ & 102 & 52 & 65 & $\begin{array}{l}\text { Two groups were compared: } \\
\text { ECMO group ( } n=26) \text { and } \\
\text { conventional mechanical } \\
\text { ventilation ( } n=26 \text { ) ARDSNet } \\
\text { protocol goals were used in } \\
\text { conventional group } \\
\text { No heparinization was used in } \\
\text { cases of emergent surgery or } \\
\text { traumatic brain injury } \\
\text { Time to ECLS: } 5 \text { days } \\
\text { Duration of ECLS: } 224 \text { h }\end{array}$ & $\begin{array}{l}\text { A significant improvement in } \\
\text { survival was found in the ECMO } \\
\text { group: } 64.7 \% \text { vs } 23.5 \% \\
\text { A significant improvement in } \\
\text { survival was also found in the } \\
\text { ECMO group after matching for } \\
\text { age and Injury Severity Score }\end{array}$ \\
\hline Wu et al. [71] & 2015 & $\begin{array}{l}\text { Retrospective } \\
\text { observational }\end{array}$ & 19 & 60 & 69 & $\begin{array}{l}\text { VV-ECMO: } 9 \text { patients } \\
\text { VA-ECMO: } 10 \text { patients } \\
\text { Heparinization: } 16(84 \%) \\
\text { patients received systemic } \\
\text { heparin } \\
\text { Time to ECLS: } 69 \mathrm{~h} \\
\text { Duration of ECLS: } 141 \mathrm{~h}\end{array}$ & $\begin{array}{l}\text { Five patients had traumatic } \\
\text { brain haemorrhage ( } 3 / 5 \\
\text { survived) } \\
\text { Five patients with systemic } \\
\text { heparinization died }(31 \%)\end{array}$ \\
\hline Jacobs et al. [74] & 2015 & $\begin{array}{l}\text { Retrospective } \\
\text { observational }\end{array}$ & 85 & $60 \pm 3$ & 74 & $\begin{array}{l}\text { VV-ECMO: } 63 \text { patients } \\
\text { VA-ECMO: } 22 \text { patients } \\
\text { Heparinization: systemic } \\
\text { heparin from } 4 \mathrm{mg} / \mathrm{kg} \text { to } \\
1.5 \mathrm{mg} / \mathrm{kg} \text { was used } \\
\text { Time to ECLS: } 95 \pm 13 \mathrm{~h} \\
\text { Duration of ECLS: } 207 \pm 24 \mathrm{~h}\end{array}$ & $\begin{array}{l}\text { Haemorrhagic complications } \\
\text { occurred in } 25 \text { cases ( } 29.4 \%) \\
\text { A shorter duration of ECMO and } \\
\text { the use of venovenous ECMO } \\
\text { were predictive criteria for } \\
\text { survival }\end{array}$ \\
\hline Bosarge et al. [70] & 2016 & $\begin{array}{l}\text { Prospective } \\
\text { controlled }\end{array}$ & 29 & 63 & 66 & $\begin{array}{l}\text { Two groups were compared : } \\
\text { ECMO group ( } n=15 \text { ) and } \\
\text { conventional mechanical } \\
\text { ventilation }(n=14) \\
\text { ARDSNet protocol goals were } \\
\text { used in conventional group } \\
\text { Heparinization: systemic } \\
\text { heparin was adapted to } \\
\text { thromboelastogram } \\
\text { Time to ECLS: } 48 \mathrm{~h} \\
\text { Duration of ECLS: } 8 \text { days }\end{array}$ & $\begin{array}{l}\text { Haemorrhagic complications } \\
\text { occurred in } 5 \text { cases ( } 33.3 \% \text { ) } \\
\text { A significant improvement in } \\
\text { survival was also found in the } \\
\text { ECMO group }\end{array}$ \\
\hline
\end{tabular}

Brownian motion. A constant mean airway pressure is maintained throughout the respiratory cycle, which is reputed to keep the alveoli open. A pressure differential around the mean pressure is generated that induces a very low tidal volume with a very high frequency [57]. HFO offers two potential advantages over conventional mechanical ventilation for patients with ARDS. First, the removal of gas convection and tidal volumes allow reduction of lung overdistention causing dynamic stress. Second, decarboxylation and oxygenation are decoupled in HFO. Decarboxylation mainly depends on the pressure differential around the mean pressure and oscillation frequencies. Oxygenation depends on the mean pressure level and $\mathrm{FiO}_{2}$. Specific adverse consequences using HFO have however to be considered: more numerous atelectasis caused by airway debris and secretions, and higher haemodynamic instability caused by the absence of alternate pressures phases. If HFO is nowadays the standard of care for refractory hypoxemia in neonatology care, its use in adults with moderate to severe ARDS was associated with a higher mortality compared to conventional ventilation even if in another multicentre study, the use of HFO had no significant effect on 30-day mortality in patients undergoing mechanical ventilation for ARDS [58]. In trauma patients, HFO ventilation was proposed as a rescue strategy when conventional mechanical ventilation did not provide sufficient oxygenation $[59,60]$. Nevertheless, some medical trials highlighted a higher mortality rate associated with the use of HFO in cases of ARDS not related to trauma [58]. Consequently, despite several physiological benefits in cases of chest trauma, the use of HFO is not recommended in clinical practice. 


\subsection{High-frequency percussive ventilation (HFPV)}

HFPV can be considered as a hybrid technique between conventional pressure control ventilation and HFO [61]. A special valve called a phasitron is used to generate diffusive gas exchange due to a high frequency (200-900/min). HFPV mainly differs than HFO by the presence of two different steady pressure levels. The frequency of alternating between two pressure levels is usually fixed at $10-15 / \mathrm{min}$, similar to conventional methods [62]. This cyclic variation of the airway pressure level limits the traditional adverse consequences induced by HFO. Other benefits of HFPV include the generation of intra-bronchial vibrations, airway turbulence and higher airflow. All these flow characteristics may enhance mobilisation and clearance of airway debris and secretions, allowing an improvement in alveolar recruitment without increasing dynamic stress. Recently, Godet et al. [63] have confirmed these benefits in CT scan study in patients with early non-focal ARDS. HFPV mode has adequate humidification of administrated gases, which allows safe prolonged. The imprecision about the parameter settings and the risk of drifting are the main reasons of the low use of this method.

In the setting of chest trauma, HFPV showed on small samples a trend of improved oxygenation in patients with ARDS, without concomitant increases in respiratory pressures [64]. These results seem contradictory with ARDS-related pneumonia, which was associated with lower oxygenation ability and lower survival [65]. Although further trials are necessary to support greater use in trauma setting, HFPV seems to be an acceptable temporary ventilation strategy in several specific critical cases, such as refractory hypoxemic pulmonary contusions or broncho-pleural disruption.

\subsection{Independent lung ventilation (ILV)}

The distribution of inspired air is dictated by the rule of minimal workload. It is mainly dependent on the properties of different lung areas. Lung compliance in cases of chest trauma is frequently altered heterogeneously or asymmetrically. In such cases, mechanical ventilation will drive a large proportion of the tidal volume towards the less affected areas, which may induce both serious overdistension of healthy parenchyma and an important ventilatory shunt in injured areas. The likelihood of volotrauma is then increased in the normal parenchyma; moreover recruitment manoeuvres are inefficient and harmful [66]. ILV is provided either by double-lumen endotracheal tube or additional endobronchial blocker, and may be synchronous and asynchronous.

Only a small number of case reports have been published on ILV in cases of ARDS after trauma [67]. In these reports, $\mathrm{FiO}_{2}$ requirements and airway pressures were reduced, and $\mathrm{PaO}_{2} /$ $\mathrm{FiO}_{2}$ and ventilation/perfusion ratio improved. Preferential use of ILV in trauma seems to be in order to establish different ventilation regimes for each lung according to their mechanical properties. This attractive concept has however been moderated by constraints of implementation. ILV is indeed challenging to achieve at the bedside; it requires accurate adjustment and cautious and specific surveillance. Furthermore, re-intubation is necessary in most cases that may be a real risk-taking in a hypoxemic patient. Tube position has to be regularly verified. Finally, although the indications for IVL are poorly defined in the literature for chest trauma, it seems reasonable to reserve this complex strategy for rare refractory patients with a unilateral severe air leak or unilateral hypoxemic massive contusions [68,69]. In these specific cases, the combination of conventional ventilation with other methods such as HFPV, or with extracorporeal support has also been described.

\subsection{High-frequency jet ventilation (HFJV)}

HFJV aims to deliver high-frequency gas pulses at high velocity and high pressure with an injector either directly through the trachea or an endotracheal tube. This is an air-leak ventilation that maintains sufficient passive gas expiration. Basal settings are the working pressure (1-4 bar), injection frequency $(1-5 \mathrm{~Hz})$ and inspiration/expiration ratio. HFJV has been described in the critical care and surgical settings as a rescue ventilatory strategy in cases of massive air leak generating respiratory failure [70]. Bronchopleural or pleuropulmonary fistulae were the main causes. The major danger with HFJV is the volotraumatic risk. Most devices do not have a pressure limitation detector, which may lead to rapid and threatening pulmonary hyperinflation if injected gases cannot be expired. A second important disadvantage with HFJV is the total absence of parameter monitoring. Finally, the main limitation of HFJV is the absence of rewarming and humidification system for injected gases for that forbids a prolonged use.

Only a few cases of HFJV use were reported in cases of chest trauma [71]. HFJV was thus proposed with success in the presence of traumatic tracheobronchial rupture, during the initial management while waiting for emergent surgical repair [72]. HFJV was not studied in cases of ARDS related to trauma. HFJV has therefore a limited place in trauma, mainly as a temporary and rescue ventilation strategy. The risks of volotrauma and mechanic tracheitis are indeed too important. Technical advances are required to warrant safe prolonged use of HFJV in critically ill patients.

\subsection{Extracorporeal assistance}

Despite small tidal volumes strategy, harmful plateau pressures may be unavoidable, refractory hypoxaemia may occur, and carbon dioxide removal may be insufficient. Extracorporeal assistance may in this case break the vicious cycle and allow a lung-protective strategy to be maintained. Extracorporeal assistance is used as a bridge to provide sufficient ventilation, oxygenation, and $\mathrm{CO}_{2}$ removal while limiting lung damage and favouring recovery of respiratory function [73]. Two extracorporeal systems are available to date: extracorporeal carbon dioxide removal, called $\mathrm{ECCO}_{2} \mathrm{R}$ or extracorporeal membrane oxygenation (ECMO). $\mathrm{ECCO}_{2} \mathrm{R}$ is a technique of partial respiratory support that achieves removal of $\mathrm{CO}_{2}$ from the blood (extracorporeal output $0.4-2 \mathrm{~L} / \mathrm{min}$ ) with poor influence on oxygenation. ECMO offers in contrast a total respiratory support due to a significant extracorporeal blood flow (3-7 L/min) [74]. ECMO requires therefore the placement of a large cannula via surgical dissection and frequently requires significant heparinisation to avoid filter clotting. ECMO can be deployed in a veno-arterial or veno-venous configuration. In medical cases of ARDS, veno-venous ECMO is mainly used in the presence of refractory massive hypoxemia under conventional mechanical ventilation and/or uncontrolled hypercapnia or acidosis [75].

In the context of trauma, ECMO was essentially studied as a rescue strategy with interesting results (Table 1). Ried et al. [73] described 52 patients requiring ECMO because of a refractory hypoxemia under conventional mechanical ventilation. The median $\mathrm{PaO}_{2} / \mathrm{FiO}_{2}$ ratio was immediately and systematically increased after initiation of ECMO, however the mortality rate was particularly low in this series (15\%). These findings corroborate results from other trials in cases of trauma [76]. Guirand et al. [77] have also shown, using a propensity score design, that venovenous ECMO was independently associated with higher survival. This increased survival was reported in two other studies [73]. Nevertheless, ECMO support remains controversial in cases 
of trauma, especially due to fear morbid haemorrhaging in patients affected by coagulopathy or injuries with a bleeding risk. Wu et al. [78] showed that haemorrhagic complications induced during ECMO were non-negligible. Several major or lethal cases of bleeding were observed in the presence of an activated partial thromboplastin time ratio between 1.5 and 2 [79]. Several major or lethal cases of bleeding were observed under ECMO support using a reasonable anticoagulation (aTTPr between 1.5 and 2) [7981]. Anticoagulation has been however proved to be not indispensable in the first days following initiation of extracorporeal assistance. Arlt et al. [82] have thus demonstrated that heparin-free ECMO improves outcome in severe trauma patients with an acceptable survival duration (mean, 5 days; range, 0.5 - 11 days). Robba et al. [83] also showed that the heparinfree veno-venous ECMO was a safe and valid option in patients with a high-risk of bleeding. The choice of cannulation sites may however lead to specific technical issues in trauma. The two main configurations are femoro-jugular and femoro-femoral cannulation. Several injuries may therefore limit or forbid the insertion of draining cannula via the femoral site; for example limb, pelvic, vascular or caval injuries. In this case, extracorporeal assistance can nonetheless be performed either by the placement of a duallumen cannula (one draining cannula and one infusion cannula) in superior vena cava, or by the use of two single-lumen cannulas in superior caval area. To summarise, the evidences supports to date that veno-venous ECMO has to be considered in chest trauma as the referent rescue strategy when hypoxaemia is refractory under maximal mechanical ventilation and/or hypercapnia is uncontrolled [84,85]. These considerations were reinforced by results of EOLIA study, which found a benefice among patients with very severe ARDS even if mortality was not significantly lower with earlier ECMO than with a strategy of conventional mechanical ventilation that included ECMO as rescue therapy [86]. Major bleeding risk will then guide the level of systemic heparinisation. In addition, with this robust indication, prophylactic use of ECMO is proposed by some experts in order to maintain ultra-protective ventilation and avoid the noxious effects of aggressive ventilation in cases of ARDS. Prospective studies are however necessary in cases of traumatic ARDS to confirm the potential benefits of this strategy.

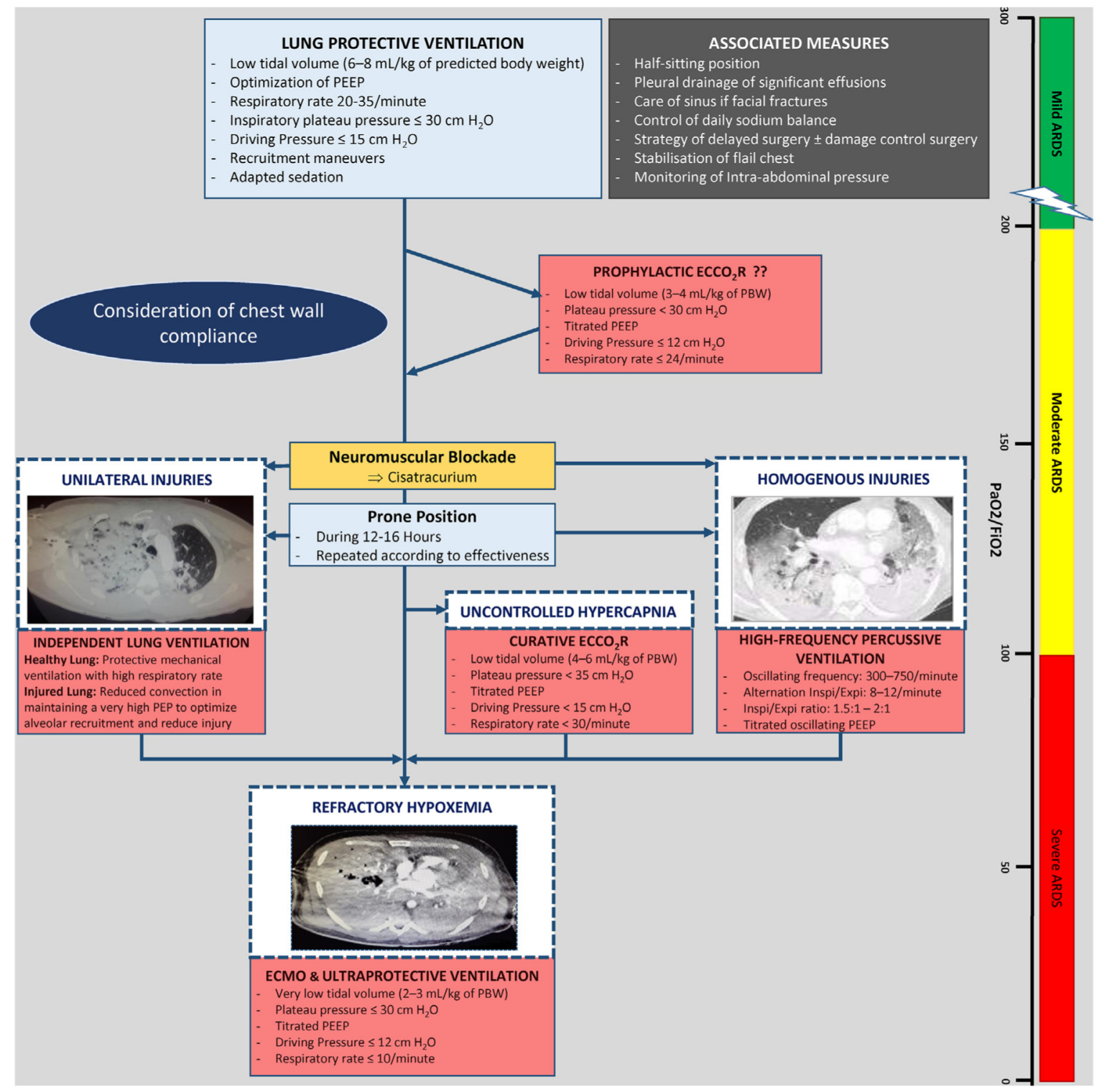

Fig. 3. Proposal of management algorithm for acute respiratory distress syndrome after chest trauma. PEEP: positive end-expiratory pressure; PBW: predicted body weight; alternation Inspi/Expi: alternation between inspiratory and expiratory phases; Inspi/Expi ratio: ratio between inspiratory time and expiratory time; ECMO: extracorporeal membrane oxygenation. 


\section{Conclusions}

Although it has its own specificities, post-traumatic ARDS has not received as much investigations as ARDS in the medical setting in recent years. The development of ARDS in cases of chest trauma has multiple causes. Its occurrence is favoured by the inflammatory cascade induced by trauma and strengthened by secondary aggression. The management of ARDS related to trauma needs to be treated on an individual basis, depending on the location and type of lung or chest injury (Fig. 3). Mechanical ventilation of chest trauma may be a real challenge because of the difficulties in achieving adequate gas exchange and lung protection. Alternative strategies to standard mechanical ventilation have a modest place in clinical practice, mainly temporally and in rescue context. ECMO should be considered in trauma patients as the main alternative when mechanical ventilation failed and survival is compromised. However, many studies are necessary to consolidate current state of knowledge.

\section{Consent for publication}

Not applicable.

\section{Availability of data and material}

Data sharing is not applicable to this article as no datasets were generated or analysed during the current study.

\section{Funding}

The authors declare that they have no sources of funding.

\section{Authors' contributions}

J.C. performed the draft of the study, S.R. and J.C. wrote the article, which S.J and X.C. read and approved the final manuscript.

\section{Disclosure of interest}

The authors declare that they have no competing interest.

\section{References}

[1] Richter T, Ragaller M. Ventilation in chest trauma. J Emerg Trauma Shock 2011;4:251-9. http://dx.doi.org/10.4103/0974-2700.82215.

[2] Szucs-Farkas Z, Kaelin I, Flach PM, Rosskopf A, Ruder TD, Triantafyllou M, et al. Detection of chest trauma with whole-body low-dose linear slit digital radiography: a multireader study. AJR Am J Roentgenol 2010;194:388-95. http:// dx.doi.org/10.2214/AJR.09.3378.

[3] Devitt JH, McLean RF, Koch JP. Anaesthetic management of acute blunt thoracic trauma. Can J Anaesth 1991;38:506-10. http://dx.doi.org/10.1007/ BF03007590.

[4] Mohta M. What's new in emergencies, trauma and shock? Mechanical ventilation in trauma patients: a tight-rope walk! J Emerg Trauma Shock 2014;7:12. http://dx.doi.org/10.4103/0974-2700.125630.

[5] Ritacca FV, Stewart TE. Clinical review: high-frequency oscillatory ventilation in adults - a review of the literature and practical applications. Crit Care Lond Engl 2003;7:385-90. http://dx.doi.org/10.1186/cc2182.

[6] Raoof S, Goulet K, Esan A, Hess DR, Sessler CN. Severe hypoxemic respiratory failure: part 2-nonventilatory strategies. Chest 2010;137:1437-48. http:// dx.doi.org/10.1378/chest.09-2416.

[7] Klein Y, Cohn SM, Proctor KG. Lung contusion: pathophysiology and management. Curr Opin Anaesthesiol 2002;15:65-8.

[8] Karcz MK. Noninvasive ventilation in trauma. World J Crit Care Med 2015;4:47. http://dx.doi.org/10.5492/wjccm.v4.i1.47.

[9] Pfeifer R, Heussen N, Michalewicz E, Hilgers R-D, Pape H-C. Incidence of adult respiratory distress syndrome in trauma patients: a systematic review and meta-analysis over a period of three decades. J Trauma Acute Care Surg 2017;83:496-506. http://dx.doi.org/10.1097/TA.0000000000001571.

[10] Bellani G, Laffey JG, Pham T, Fan E, Brochard L, Esteban A, et al. Epidemiology, patterns of care, and mortality for patients with acute respiratory distress syndrome in intensive care units in 50 countries. JAMA 2016;315:788-800. http://dx.doi.org/10.1001/jama.2016.0291.

[11] Navarrete-Navarro P, Rodriguez A, Reynolds N, West R, Rivera R, Scalea T. Adult respiratory distress syndrome among blunt and penetrating trauma patients: demographics, mortality, and resource utilization over 8 years. J Crit Care 2001;16:47-53. http://dx.doi.org/10.1053/jcrc.2001.25230.

[12] Leone M, Brégeon F, Antonini F, Chaumoître K, Charvet A, Ban LH, et al. Longterm outcome in chest trauma: Anesthesiology 2008;109:864-871. 10.1097/ ALN.0b013e31818a4009.

[13] Tyburski JG, Collinge JD, Wilson RF, Eachempati SR. Pulmonary contusions: quantifying the lesions on chest $\mathrm{X}$-ray films and the factors affecting prognosis. J Trauma 1999;46:833-8.

[14] Forel J-M, Voillet F, Pulina D, Gacouin A, Perrin G, Barrau K, et al. Ventilatorassociated pneumonia and ICU mortality in severe ARDS patients ventilated according to a lung-protective strategy. Crit Care 2012;16:R65. http:// dx.doi.org/10.1186/cc11312.

[15] Haider T, Halat G, Heinz T, Hajdu S, Negrin LL. Thoracic trauma and acute respiratory distress syndrome in polytraumatized patients: a retrospective analysis. Minerva Anestesiol 2017;83:1026-33. http://dx.doi.org/10.23736/ S0375-9393.17.11728-1.

[16] Miller PR, Croce MA, Bee TK, Qaisi WG, Smith CP, Collins GL, et al. ARDS after pulmonary contusion: accurate measurement of contusion volume identifies high-risk patients. J Trauma 2001;51:223-8 [discussion 229-230].

[17] Leblanc D, Bouvet C, Degiovanni F, Nedelcu C, Bouhours G, Rineau E, et al. Early lung ultrasonography predicts the occurrence of acute respiratory distress syndrome in blunt trauma patients. Intensive Care Med 2014;40:1468-74. http://dx.doi.org/10.1007/s00134-014-3382-9.

[18] Hudson LD, Milberg JA, Anardi D, Maunder RJ. Clinical risks for development of the acute respiratory distress syndrome. Am J Respir Crit Care Med 1995;151:293-301. http://dx.doi.org/10.1164/ajrccm.151.2.7842182.

[19] Calfee CS, Eisner MD, Ware LB, Thompson BT, Parsons PE, Wheeler AP, et al. Trauma-associated lung injury differs clinically and biologically from acute lung injury due to other clinical disorders. Crit Care Med 2007;35:2243-50.

[20] Wanek S, Mayberry JC. Blunt thoracic trauma: flail chest, pulmonary contusion, and blast injury. Crit Care Clin 2004;20:71-81.

[21] Suresh MV, Ramakrishnan SK, Thomas B, Machado-Aranda D, Bi Y, Talarico N, et al. Activation of hypoxia-inducible factor- $1 \alpha$ in type 2 alveolar epithelial cell is a major driver of acute inflammation following lung contusion. Crit Care Med 2014;42:e642-53. http://dx.doi.org/10.1097/CCM.0000000000000488.

[22] Bulger EM, Edwards T, Klotz P, Jurkovich G]. Epidural analgesia improves outcome after multiple rib fractures. Surgery 2004;136:426-30. http:// dx.doi.org/10.1016/i.surg.2004.05.019.

[23] Galvagno SM, Smith CE, Varon AJ, Hasenboehler EA, Sultan S, Shaefer G, et al. Pain management for blunt thoracic trauma: a joint practice management guideline from the eastern association for the surgery of trauma and trauma anesthesiology society. J Trauma Acute Care Surg 2016. http://dx.doi.org/ 10.1097/TA.0000000000001209.

[24] Daurat A, Millet I, Roustan J-P, Maury C, Taourel P, Jaber S, et al. Thoracic Trauma Severity score on admission allows to determine the risk of delayed ARDS in trauma patients with pulmonary contusion. Injury 2016;47:147-53. http://dx.doi.org/10.1016/j.injury.2015.08.031.

[25] Hwang S-W, Kim H-Y, Byun JH. Management of patients with traumatic rupture of the diaphragm. Korean J Thorac Cardiovasc Surg 2011;44:34854. http://dx.doi.org/10.5090/kjtcs.2011.44.5.348.

[26] Niesler U, Palmer A, Radermacher P, Huber-Lang MS. Role of alveolar macrophages in the inflammatory response after trauma. Shock Augusta Ga 2014;42:3-10. http://dx.doi.org/10.1097/SHK.0000000000000167.

[27] Xiao W, Mindrinos MN, Seok J, Cuschieri J, Cuenca AG, Gao H, et al. A genomic storm in critically injured humans. J Exp Med 2011;208:2581-90. http:// dx.doi.org/10.1084/jem.20111354.

[28] Xu W, Song Y. Biomarkers for patients with trauma associated acute respiratory distress syndrome. Mil Med Res 2017;4:25. http://dx.doi.org/10.1186/ s40779-017-0134-5.

[29] Agrawal A, Matthay MA, Kangelaris KN, Stein J, Chu JC, Imp BM, et al. Plasma angiopoietin-2 predicts the onset of acute lung injury in critically ill patients. Am J Respir Crit Care Med 2013;187:736-42. http://dx.doi.org/10.1164/ rccm.201208-14600C

[30] Jabaudon M, Futier E, Roszyk L, Chalus E, Guerin R, Petit A, et al. Soluble form of the receptor for advanced glycation end products is a marker of acute lung injury but not of severe sepsis in critically ill patients. Crit Care Med 2011;39:480-8. http://dx.doi.org/10.1097/CCM.0b013e318206b3ca.

[31] Ware LB, Koyama T, Zhao Z, Janz DR, Wickersham N, Bernard GR, et al. Biomarkers of lung epithelial injury and inflammation distinguish severe sepsis patients with acute respiratory distress syndrome. Crit Care Lond Engl 2013;17:R253. http://dx.doi.org/10.1186/cc13080.

[32] Wutzler S, Backhaus L, Henrich D, Geiger E, Barker J, Marzi I, et al. Clara cell protein 16: a biomarker for detecting secondary respiratory complications in patients with multiple injuries. J Trauma Acute Care Surg 2012;73:838-42. http://dx.doi.org/10.1097/TA.0b013e31825ac394.

[33] Wutzler S, Wafaisade A, Maegele M, Laurer H, Geiger EV, Walcher F, et al. Lung Organ Failure Score (LOFS): probability of severe pulmonary organ failure after multiple injuries including chest trauma. Injury 2012;43:1507-12. http:// dx.doi.org/10.1016/j.injury.2010.12.029.

[34] Driessen A, Fröhlich M, Schäfer N, Mutschler M, Defosse JM, Brockamp T, et al. Prehospital volume resuscitation - Did evidence defeat the crystalloid dogma? An analysis of the TraumaRegister DGU ${ }^{\mathbb{N}}$ 2002-2012. Scand J Trauma Resusc Emerg Med 2016;24:42. http://dx.doi.org/10.1186/s13049-016-02334.

[35] Holcomb JB, Tilley BC, Baraniuk S, Fox EE, Wade CE, Podbielski JM, et al. Transfusion of plasma, platelets, and red blood cells in a $1: 1: 1$ vs a $1: 1: 2$ ratio 
and mortality in patients with severe trauma. JAMA 2015;313:471-82. http:// dx.doi.org/10.1001/jama.2015.12.

[36] Dunham CM, Bosse MJ, Clancy TV, Cole FJ, Coles MJ, Knuth T, et al. Practice management guidelines for the optimal timing of long-bone fracture stabilization in polytrauma patients: the EAST Practice Management Guidelines Work Group. J Trauma 2001:50:958-67.

[37] Jiang M, Li C, Yi C, Tang S. Early intramedullary nailing of femoral shaft fracture on outcomes in patients with severe chest injury: a meta-analysis. Sci Rep 2016;6:30566. http://dx.doi.org/10.1038/srep30566.

[38] Pape HC, Auf' molk M, Paffrath T, Regel G, Sturm JA, Tscherne H. Primary intramedullary femur fixation in multiple trauma patients with associated lung contusion - a cause of posttraumatic ARDS? J Trauma 1993;34:540-7 [547-548].

[39] Rao PM, Puri GD, Bharadwaj N, Chari P, Acup D. ICU management of blunt chest trauma: our experience. Ann Card Anaesth 1998;1:31-5.

[40] Chiumello D, Carlesso E, Cadringher P, Caironi P, Valenza F, Polli F, et al. Lung stress and strain during mechanical ventilation for acute respiratory distress syndrome. Am J Respir Crit Care Med 2008;178:346-55. http://dx.doi.org/ 10.1164/rccm.200710-15890C.

[41] Acute Respiratory Distress Syndrome Network, Brower RG, Matthay MA, Morris A, Schoenfeld D, Thompson BT, Wheeler AVentilation with lower tidal volumes as compared with traditional tidal volumes for acute lung injury and the acute respiratory distress syndrome. The acute respiratory distress syndrome network. N Engl J Med 2000;342:1301-8. http://dx.doi.org/10.1056/ NEJM200005043421801.

[42] Meade MO, Cook DJ, Guyatt GH, Slutsky AS, Arabi YM, Cooper DJ, et al. Ventilation strategy using low tidal volumes, recruitment maneuvers, and high positive end-expiratory pressure for acute lung injury and acute respiratory distress syndrome: a randomized controlled trial. JAMA 2008;299:63745. http://dx.doi.org/10.1001/jama.299.6.637.

[43] Papadakos PJ, Karcz M, Lachmann B. Mechanical ventilation in trauma. Curr Opin Anaesthesiol 2010;23:228-32. http://dx.doi.org/10.1097/ACO.0b013e328336ea6e.

[44] Papazian L, Forel J-M, Gacouin A, Penot-Ragon C, Perrin G, Loundou A, et al. Neuromuscular blockers in early acute respiratory distress syndrome. $\mathrm{N}$ Engl J Med 2010;363:1107-16. http://dx.doi.org/10.1056/NEJMoa1005372.

[45] Guérin C, Reignier J, Richard J-C, Beuret P, Gacouin A, Boulain T, et al. Prone positioning in severe acute respiratory distress syndrome. $\mathrm{N}$ Engl J Med 2013;368:2159-68. http://dx.doi.org/10.1056/NEJMoa1214103.

[46] Domino KB. Prevention of eye injuries in anaesthesia and intensive care: new expert guidelines. Anaesth Crit Care Pain Med 2017;36:351-2. http:/l dx.doi.org/10.1016/j.accpm.2017.11.005

[47] French Society of Anesthesia and resuscitation an French Society of Emergency Medicine. In: Traumatisme thoracique : prise en charge des 48 premières heures. Société Française D’Anesthésie Réanimation (SFAR); 2015 [http:// sfar.org/traumatisme-thoracique-prise-en-charge-des-48-premieres-heures/ accessed October 5, 2016]

[48] Schreiter D, Carvalho NC, Katscher S, Mende L, Reske AP, Spieth PM, et al. Experimental blunt chest trauma - cardiorespiratory effects of different mechanical ventilation strategies with high positive end-expiratory pressure: a randomized controlled study. BMC Anesthesiol 2016;16:3. http://dx.doi.org/ 10.1186/s12871-015-0166-X.

[49] Schreiter D, Reske A, Scheibner L, Glien C, Katscher S, Josten C. [The open lung concept. Clinical application in severe thoracic trauma]. Chir Z Alle Geb Oper Medizen 2002;73:353-9. http://dx.doi.org/10.1007/s00104-001-0389-x.

[50] Imai Y, Parodo J, Kajikawa O, de Perrot M, Fischer S, Edwards V, et al. Injurious mechanical ventilation and end-organ epithelial cell apoptosis and organ dysfunction in an experimental model of acute respiratory distress syndrome. JAMA 2003;289:2104-12. http://dx.doi.org/10.1001/jama.289.16.2104.

[51] Maung AA, Kaplan LJ. Airway pressure release ventilation in acute respiratory distress syndrome. Crit Care Clin 2011;27:501-9. http://dx.doi.org/10.1016/ j.ccc.2011.05.003.

[52] Zhou Y, Jin X, Lv Y, Wang P, Yang Y, Liang G, et al. Early application of airway pressure release ventilation may reduce the duration of mechanical ventilation in acute respiratory distress syndrome. Intensive Care Med 2017;43:1648-59. http://dx.doi.org/10.1007/s00134-017-4912-z.

[53] Jain SV, Kollisch-Singule M, Sadowitz B, Dombert L, Satalin J, Andrews P, et al. The 30-year evolution of airway pressure release ventilation (APRV). Intensive Care Med Exp 2016;4:11. http://dx.doi.org/10.1186/s40635-016-0085-2.

[54] Maxwell RA, Green JM, Waldrop J, Dart BW, Smith PW, Brooks D, et al. A randomized prospective trial of airway pressure release ventilation and low tidal volume ventilation in adult trauma patients with acute respiratory failure. J Trauma 2010;69:501-10. http://dx.doi.org/10.1097/ TA.0b013e3181e75961 [discussion 511].

[55] Maung AA, Schuster KM, Kaplan LJ, Ditillo MF, Piper GL, Maerz LL, et al. Compared to conventional ventilation, airway pressure release ventilation may increase ventilator days in trauma patients. J Trauma Acute Care Surg 2012;73:507-10.

[56] Andrews PL, Shiber JR, Jaruga-Killeen E, Roy S, Sadowitz B, O'Toole RV, et al. Early application of airway pressure release ventilation may reduce mortality in high-risk trauma patients: a systematic review of observational trauma ARDS literature. J Trauma Acute Care Surg 2013;75:635-41. http://dx.doi.org/ 10.1097/TA.0b013e31829d3504.

[57] Hager DN, Fessler HE, Kaczka DW, Shanholtz CB, Fuld MK, Simon BA, et al. Tidal volume delivery during high-frequency oscillatory ventilation in adults with acute respiratory distress syndrome. Crit Care Med 2007;35:1522-9. http:// dx.doi.org/10.1097/01.CCM.0000266586.04676.55.

[58] Ferguson ND, Cook DJ, Guyatt GH, Mehta S, Hand L, Austin P, et al. Highfrequency oscillation in early acute respiratory distress syndrome. N Engl J Med 2013;368:795-805. http://dx.doi.org/10.1056/NEJMoa1215554.

[59] Funk DJ, Lujan E, Moretti EW, Davies J, Young CC, Patel MB, et al. A brief report: the use of high-frequency oscillatory ventilation for severe pulmonary contusion. J Trauma 2008;65:390-5. http://dx.doi.org/10.1097/TA.0b013e31817f283f.

[60] Vrettou CS, Zakynthinos SG, Malachias S, Mentzelopoulos SD. High-frequency oscillation and tracheal gas insufflation in patients with severe acute respiratory distress syndrome and traumatic brain injury: an interventional physiological study. Crit Care Lond Engl 2013;17:R136. http://dx.doi.org/10.1186/ cc12815.

[61] Lucangelo U, Antonaglia V, Gullo A, Zin WA. High-frequency percussive ventilation. Crit Care Med 2005;33:2155-6.

[62] Eastman A, Holland D, Higgins J, Smith B, Delagarza J, Olson C, et al. Highfrequency percussive ventilation improves oxygenation in trauma patients with acute respiratory distress syndrome: a retrospective review. Am J Surg 2006;192:191-5. http://dx.doi.org/10.1016/j.amjsurg.2006.01.021.

[63] Godet T, Jabaudon M, Blondonnet R, Tremblay A, Audard J, Rieu B, et al. High frequency percussive ventilation increases alveolar recruitment in early acute respiratory distress syndrome: an experimental, physiological and CT scan study. Crit Care Lond Engl 2018;22:3. http://dx.doi.org/10.1186/s13054-0171924-6.

[64] Salim A, Miller K, Dangleben D, Cipolle M, Pasquale M. High-frequency percussive ventilation: an alternative mode of ventilation for head-injured patients with adult respiratory distress syndrome. J Trauma 2004;57:542-6.

[65] Spapen H, Borremans M, Diltoer M, Gorp VV, Nguyen DN, Honoré PM. Highfrequency percussive ventilation in severe acute respiratory distress syndrome: a single center experience. J Anaesthesiol Clin Pharmacol 2014;30:65-70. http://dx.doi.org/10.4103/0970-9185.125706.

[66] Rico FR, Cheng JD, Gestring ML, Piotrowski ES. Mechanical ventilation strategies in massive chest trauma. Crit Care Clin 2007;23:299-315. http:/l dx.doi.org/10.1016/j.ccc.2006.12.007 [xi].

[67] Katsaragakis S, Stamou KM, Androulakis G. Independent lung ventilation for asymmetrical chest trauma: effect on ventilatory and haemodynamic parameters. Injury 2005;36:501-4. http://dx.doi.org/10.1016/j.injury.2004.10.009.

[68] Cinnella G, Dambrosio M, Brienza N, Giuliani R, Bruno F, Fiore T, et al. Independent lung ventilation in patients with unilateral pulmonary contusion. Monitoring with compliance and EtCO(2). Intensive Care Med 2001;27:1860_ 7. http://dx.doi.org/10.1007/s00134-001-1149-6.

[69] Sawulski S, Nestorowicz A, Wośko J, Dąbrowski W, Kowalczyk M, Fijałkowska A. Independent lung ventilation for treatment of post-traumatic ARDS. Anaesthesiol Intensive Ther 2012;44:84-8.

[70] Roustan JP. [High frequency jet ventilation combined with conventional mechanical ventilation in the treatment of adult respiratory distress syndrome]. Ann Fr Anesth Reanim 1995;14:276-88.

[71] Riou B, Zaier K, Kalfon P, Puybasset L, Coriat P, Rouby JJ. High-frequency jet ventilation in life-threatening bilateral pulmonary contusion. Anesthesiology 2001;94:927-30.

[72] Naghibi K, Hashemi SL, Sajedi P. Anaesthetic management of tracheobronchial rupture following blunt chest trauma. Acta Anaesthesiol Scand 2003;47:9013. http://dx.doi.org/10.1034/j.1399-6576.2003.00179.x.

[73] Ried M, Bein T, Philipp A, Müller T, Graf B, Schmid C, et al. Extracorporeal lung support in trauma patients with severe chest injury and acute lung failure: a 10-year institutional experience. Crit Care Lond Engl 2013;17:R110. http:// dx.doi.org/10.1186/cc12782.

[74] Camporota L, Barrett N. Current applications for the use of extracorporeal carbon dioxide removal in critically ill patients. BioMed Res Int 2016;2016. http://dx.doi.org/10.1155/2016/9781695.

[75] Peek GJ, Mugford M, Tiruvoipati R, Wilson A, Allen E, Thalanany MM, et al. Efficacy and economic assessment of conventional ventilatory support versus extracorporeal membrane oxygenation for severe adult respiratory failure (CESAR): a multicentre randomised controlled trial. Lancet Lond Engl 2009;374:1351-63. http://dx.doi.org/10.1016/S0140-6736(09)61069-2.

[76] Bonacchi M, Spina R, Torracchi L, Harmelin G, Sani G, Peris A. Extracorporeal life support in patients with severe trauma: an advanced treatment strategy for refractory clinical settings. J Thorac Cardiovasc Surg 2013;145:1617-26. http://dx.doi.org/10.1016/j.jtcvs.2012.08.046.

[77] Guirand DM, Okoye OT, Schmidt BS, Mansfield NJ, Aden JK, Martin RS, et al. Venovenous extracorporeal life support improves survival in adult trauma patients with acute hypoxemic respiratory failure: a multicenter retrospective cohort study. J Trauma Acute Care Surg 2014;76:1275-81. http://dx.doi.org/ 10.1097/TA.0000000000000213.

[78] Wu S-C, Chen WT-L, Lin H-H, Fu C-Y, Wang Y-C, Lo H-C, et al. Use of extracorporeal membrane oxygenation in severe traumatic lung injury with respiratory failure. Am J Emerg Med 2015;33:658-62. http://dx.doi.org/ 10.1016/j.ajem.2015.02.007.

[79] Wu M-Y, Lin P-J, Tseng Y-H, Kao K-C, Hsiao H-L, Huang C-C. Venovenous extracorporeal life support for posttraumatic respiratory distress syndrome in adults: the risk of major hemorrhages. Scand J Trauma Resusc Emerg Med 2014;22:56. http://dx.doi.org/10.1186/s13049-014-0056-0.

[80] Cordell-Smith JA, Roberts N, Peek GJ, Firmin RK. Traumatic lung injury treated by extracorporeal membrane oxygenation (ECMO). Injury 2006;37:29-32. http://dx.doi.org/10.1016/j.injury.2005.03.027. 
[81] Jacobs JV, Hooft NM, Robinson BR, Todd E, Bremner RM, Petersen SR, et al. The use of extracorporeal membrane oxygenation in blunt thoracic trauma: a study of the extracorporeal life support organization database. J Trauma Acute Care Surg 2015;79:1049-53. http://dx.doi.org/10.1097/ TA.0000000000000790 [1053-1054].

[82] Arlt M, Philipp A, Voelkel S, Rupprecht L, Mueller T, Hilker M, et al. Extracorporeal membrane oxygenation in severe trauma patients with bleeding shock. Resuscitation 2010;81:804-9. http://dx.doi.org/10.1016/j.resuscitation.2010.02.020.

[83] Robba C, Ortu A, Bilotta F, Lombardo A, Sekhon MS, Gallo F, et al. Extracorporeal membrane oxygenation for adult respiratory distress syndrome in trauma patients: a case series and systematic literature review. J Trauma Acute Care Surg 2017;82:165-73. http://dx.doi.org/10.1097/TA.0000000000001276.
[84] Biderman P, Einav S, Fainblut M, Stein M, Singer P, Medalion B. Extracorporeal life support in patients with multiple injuries and severe respiratory failure: a single-center experience? J Trauma Acute Care Surg 2013;75:907-12. http:// dx.doi.org/10.1097/TA.0b013e3182a8334f.

[85] Bosarge PL, Raff LA, McGwin G, Carroll SL, Bellot SC, Diaz-Guzman E, et al. Early initiation of extracorporeal membrane oxygenation improves survival in adult trauma patients with severe adult respiratory distress syndrome. J Trauma Acute Care Surg 2016;81:236-43. http://dx.doi.org/10.1097/ TA.0000000000001068.

[86] Combes A, Hajage D, Capellier G, Demoule A, Lavoué S, Guervilly C, et al. Extracorporeal membrane oxygenation for severe acute respiratory distress syndrome. N Engl J Med 2018;378:1965-75. http://dx.doi.org/10.1056/NEJMoa1800385. 